Abstracta Iranica Abstracta Iranica

Revue bibliographique pour le domaine irano-aryen

Volume 25 | 2004

Comptes rendus des publications de 2002

\title{
«Traces d'un ancien rite assyrien dans les Actes de Mar Mari ». Semitica 51 (2001), pp. 65-71.
}

\section{Simon C. Mimouni}

\section{(2) OpenEdition}

1 Journals

\section{Édition électronique}

URL : http://journals.openedition.org/abstractairanica/4830

DOI : 10.4000/abstractairanica.4830

ISSN : 1961-960X

Éditeur :

CNRS (UMR 7528 Mondes iraniens et indiens), Éditions de l'IFRI

\section{Édition imprimée}

Date de publication : 15 mai 2004

ISSN : 0240-8910

\section{Référence électronique}

Simon C. Mimouni, « «Traces d'un ancien rite assyrien dans les Actes de Mar Mari ». Semitica 51 (2001), pp. 65-71. », Abstracta Iranica [En ligne], Volume 25 | 2004, document 235, mis en ligne le 15 mars 2006, consulté le 25 septembre 2020. URL : http://journals.openedition.org/abstractairanica/ 4830 ; DOI : https://doi.org/10.4000/abstractairanica.4830

Ce document a été généré automatiquement le 25 septembre 2020.

Tous droits réservés 


\title{
«Traces d'un ancien rite assyrien dans les Actes de Mar Mari ». Semitica 51 (2001), pp. 65-71.
}

\author{
Simon C. Mimouni
}

Dans les Actes de Mar Mari, au § 11, il est rapporté un rite qui consiste à faire passer son fils ou sa fille par le feu - un rite présent en Assour et à Arbèles mais aussi bien attesté dans la Bible car largement pratiqué par le peuple de Judée et surtout par les habitants de Jérusalem. Il se pourrait qu'il s'agisse dans ce texte d'une réminiscence d'un rite local dont les documents assyriens ont conservé la trace pour une période bien plus ancienne : si tel était le cas, la permanence de cette expression pour un rite pratiqué dans la région d'Arbèles à travers les siècles serait vraiment remarquable. Il n'en demeure pas moins que le passage des Actes de Mar Mari ait pu être inspiré de la Bible, appliquant mécaniquement aux populations païennes de Mésopotamie un exemple particulièrement frappant des cultes idolâtres qui se sont introduits en Juda plus de dix siècles auparavant.

INDEX

Thèmes : 6.3. Autres religions 
AUTEURS

SIMON C. MIMOUNI

EPHE - Paris 